\title{
Agile Entrepreneurship Innovation in Fashion Design Thinking During COVID-19 and Beyond: Reimagine Education to Create Skills for Fashion Business
}

\author{
Vasiliki A. Basdekidou ${ }^{1}$ \\ ${ }^{1}$ Department of Creative Design \& Clothing, School of Design Sciences, International Hellenic University, \\ Greece \\ Correspondence: Vasiliki A. Basdekidou, the International Hellenic University, 14th km Thessaloniki - N. \\ Moudania National Road, 57001 Thermi, Greece. E-mail: Vasiliki.Basdekidou@gmail.com
}

Received: April 21, 2021

Accepted: June 30, 2021

Online Published: July 8, 2021

doi:10.5539/ijef.v13n8p1

URL: https://doi.org/10.5539/ijef.v13n8p1

\begin{abstract}
Purpose: The COVID-19 crisis had a severe impact on University education (on-line learning, off-campus examinations). In addition, the COVID-19 pandemic raises questions about the quality of education and training in a number of disciplines, like fashion design, where social entrepreneurship opportunities and in-situ functionalities are essential for a quality curriculum. Hence, to remain relevant and innovative, fashion design thinking will need to reimagine education in order to create skills for e-entrepreneurship and prepare fashion entrepreneurs for e-business. Therefore, new concepts for fashion design thinking for innovation and e-entrepreneurship have to introduce in an e-classrooms curriculum.

Methodology: This study employed the use of questionnaires to collect quantitative data and structured interviews to compile qualitative data (opinions) of two main groups of fashion design professionals: (a) clothing merchants and manufacturers, (b) fashion design green entrepreneurs. In particular, linear regression used to analyze the quantitative data (SPSS functionality) and data analytics software (QSR NVivo) adopted to encode the answers from the interviews.

Findings: Findings obtained in this study show that -with the admission of agile entrepreneurship superiority and functional solution in crises like COVID-19- the green entrepreneurs are better positioning are better prepared to withstand the current COVID-19 or future crisis. Hence the requirement to integrate green entrepreneurship courses into the fashion d esign curriculum will be proposed to create innovation and value in fashion design thinking.

Originality and value: This study inserts itself in a multidisciplinary field, mainly composed of four disciplinary areas: "fashion design thinking and education", "digital transformation", "green entrepreneurship", and "work-from-home entrepreneurship". The introduction of the new term "Agile entrepreneurship" as a new disciplinary concept in fashion design curriculum is also crucial.

Research limitations: The main limitation of this study is related to the definition of "Agile entrepreneurship" itself in COVID-19 and beyond work-from-home era, as bibliography still diverges on this subject.
\end{abstract}

Keywords: agile entrepreneurship, fashion design thinking, digital transformation, green entrepreneurship, work-from-home entrepreneurship

\section{Introduction}

\subsection{Introduce the Problem}

The Greek fashion design industry has indubitably experienced many changes in the last few years and the COVID-19 crisis has been the catalyst for unemployment and austerity. Greece and many other EU countries have also experienced a major augmentation regarding higher-education demand from students (Manzini, 2012).

Design thinking innovative disciplines, like fashion design are directly linked to concepts like entrepreneurship, green entrepreneurship, and digital transformation. Work-from-home entrepreneurship has also been unquestionably one of the most used words in 2020-2021 years. In this context, work-from-home entrepreneurship is now considered by public opinion on a global scale as an objective of improvement and an 
opportunity for profit.

This article introduces the innovative concept "Agile entrepreneurship in fashion design thinking". Agile methodology involves gradual planning on an ongoing basis as well as greater flexibility instead of creating five-year plans for major projects. Essentially, the company is expected to constantly adapt to new changes and customer or stakeholder feedback on a regular basis. The introduced concept "Agile entrepreneurship in fashion design thinking" is defined as following in order to become a term. Agile entrepreneurship in fashion design thinking involves the functional integration of the following terms in fashion design entrepreneurship:

1) Digital transformation \& Big data;

2) Business intelligence solutions \& Company strategy;

3) Product development services \& Optimized delivery solutions;

4) Social and email marketing \& Marketing Automation research;

5) Digital consultancy services \& Solutions;

6) Corporate performance management; and

7) Creative design \& Content architecture.

These seven 7 terms are considered as the ground-truth hypotheses on evaluated the data from the questionnaires (quantitative data) and the structured interviews (qualitative data, opinions) collected in the context of article's research to assess the response of fashion design companies to the COVID-19 crisis. Each of these seven terms raised two research questions for the performed market survey in fashion design companies. So, the questionnaires and the interviews have been structured around these fourteen (14) research questions.

\subsection{Importance of the Problem}

The COVID-19 crisis had a severe impact on University education raises questions about the quality of education and training in fashion design courses, where social entrepreneurship opportunities and in-situ functionalities are essential for a quality curriculum. Hence, to remain relevant and innovative, fashion design thinking will need to reimagine education in order to create skills for e-entrepreneurship and prepare fashion entrepreneurs for e-business. Therefore, new concepts for fashion design thinking for innovation and e-entrepreneurship have to introduce in an e-classrooms curriculum.

Additionally, by exploring agile entrepreneurship (the application of the principles of agile entrepreneurship development to various management processes, particularly project management) and innovation in fashion design thinking; established fashion design (university) education courses will prepared for the new challenges and new sustainable skills will created for fashion design business in general including people, structures, and companies (Nonaka \& Hirotaka, 2019). Hence, it is too important to understand what specific skills and attitudes the new fashion designers lack and must acquire during their education/training and before it comes to creating their own venture (Patrice Muller et al., 2017),

\subsection{The Research Questions}

In this domain, the research questions are structured as following:
(1) Agile development
(2) Data Analytics, Artificial Intelligence (AI)
(3) Intelligence automation services
(4) Machine-learning
(5) Product information management
(6) Custom product portfolio
(7) Social media services
(8) Competitive positioning
(9) Management consulting
(10) Organizational change management areas
(11) Custom relationship management
(12) Order management solutions and services
(13) Content management system
(14) Conversion rate optimization

Hence, by interpreting the result of a survey/questionnaire, clear conclusions should drawn for (i) understanding what specific skills, knowledge, and attitudes young fashion designer entrepreneurs lack when it comes to start their venture in this industry; and (ii) a better, functional and sustainable, organization (prepared for the new challenges) of the curricula of fashion design educational departments should designed for the preparation of graduates for facing and dealing with crises like COVID-19. 


\subsection{Describe Relevant Scholarship}

In relevant related literature, Clara Eloise Fernandes from the University of Beira Interior (Portugal) describe fashion entrepreneurship and the skills and solutions to create a fashion business, but do not feel compelled to include agile entrepreneurship functionalities (Fernandes, 2019). Segonds, Mantelet, Maranzana, and Gaillard discuss early stages of apparel design and how to define collaborative needs for fashion design, but no information is given for collaborative design and fashion design thinking in distance learning courses (e-education) (Segonds et al., 2020). Darrell Rigby, Jeff Sutherland, and Hirotaka Takeuchi embracing agile in mastering the process on transforming management to digital era, but without including "big data" an important concept in todays fashion design thinking (Darrell et al., 2016).

Ernest Samwel Mwasalwiba, in a classical text, discusses entrepreneurship education while reviewing of its objectives, teaching methods, and impact indicators, but no details on digital transformation, product development services and optimized delivery solutions are described (Mwasalwiba, 2010). Runco M.A. discusses creativity theories and themes as well as research, development, and practice for SMEs and entrepreneurship in an EU/EUROSTAT report, but without dealing with corporate performance management (Runco, 2014).

Wenting Rik embracing pinoff dynamics and the spatial formation of the fashion design industry, but no any reference $t \mathrm{o}$ creative design and content architecture in fashion design thinking (Wenting, 2008).

Generally, no documented aspects on marketing automation research (e.g. e-shop development and running) and on applying e-education in fashion design courses and business intelligent solutions/company strategies have reported (Nonaka \& Hirotaka, 2019).

\section{Method - The Ground-truth Hypotheses \& The Research Questions}

Fashion design thinking for innovation and entrepreneurship in the COVID-19 era and beyond is the core of the questionnaires and interviews. In particular, the following 12 questions were asked and discussed in the context of the 6 ground-truth hypotheses. See Table 1 (Hypotheses \& Research Questions):

Table 1. Hypotheses \& research questions

\begin{tabular}{|c|c|}
\hline Hypotheses & Research Questions \\
\hline (1) & \#1 Are the fashion design courses prepared for this or similar challenge ahead? \\
\hline Digital Transformation & Do you think your company has an agile development functionality? \\
\hline \multirow[t]{2}{*}{$\&$ Big data } & \#2 How much the COVID-19 pandemic affected your entrepreneurial activity? \\
\hline & Do you use Data analytics and Artificial Intelligence software? \\
\hline \multirow{2}{*}{$\begin{array}{c}(2) \\
\text { Business intelligent solutions }\end{array}$} & \#3 In a society that is more entrepreneurial than ever, do you think your company has an intelligent \\
\hline & automation services protocol? \\
\hline \multirow{2}{*}{$\begin{array}{c}\& \\
\text { Company strategy }\end{array}$} & \#4 Do you believe that your work will decrease due to the COVID-19 pandemic? \\
\hline & Are you thinking to acquire machine-learning software? \\
\hline \multirow{5}{*}{$\begin{array}{c}\text { (3) } \\
\text { Product development services } \\
\& \\
\text { Optimized delivery solutions }\end{array}$} & \#5 If your business will not get funded by the Government, what do you plan to do (would you put your \\
\hline & personal capital or would you wait for a funding opportunity)? Are you thinking on incorporating product \\
\hline & information management functionality? \\
\hline & \#6 Does the possibility of an e-shop frighten you? Do you believe in it? \\
\hline & Do you need a custom product portfolio? \\
\hline \multirow{5}{*}{$\begin{array}{c}\text { (4) } \\
\text { Social and email marketing } \\
\& \\
\text { Marketing automation } \\
\text { research } \\
\end{array}$} & \#7 Could you start an e-shop? \\
\hline & Do you plan to, would this possibility interest you, in terms of the pandemic? \\
\hline & Are you thinking social media services functionality? \\
\hline & \#8 Could you support an e-shop? \\
\hline & Do you feel a competitive positioning? \\
\hline \multirow{3}{*}{$\begin{array}{c}(5) \\
\text { Digital consultancy services } \\
\&\end{array}$} & \#9 Do you think your employees have had adequate background for on-line management? \\
\hline & Do you need management consulting? \\
\hline & \#10 Have you considered transformation to information technology? \\
\hline Solutions & Are you thinking for organizational change management areas? \\
\hline \multirow{4}{*}{$\begin{array}{c}\text { (6) } \\
\text { Corporate performance } \\
\text { management }\end{array}$} & \#11 What specific skills, knowledge, education, and attitudes do the young fashion designers (in your \\
\hline & company) lack? \\
\hline & Do you need custom relationship management? \\
\hline & \#12 Which are the solutions that already are available or can be launched to help young fashion designers? \\
\hline
\end{tabular}


Are you thinking for ordering management solutions and services?

Have you already prepared your financial plan on it?

(7) Do you use a content management system?

Creative design

$\&$

Content Architecture
\#13 Are you satisfied about the creative design functionality in your company?

Are your young fashion designers have had operate a content management system?

\#14 Are you satisfied about the content architecture functionality in your company? Do you think for conversion rate optimization?

Are your young fashion designers have had these specific skills, knowledge, education, and attitudes to support a conversion rate optimization?

The research questions, actually, reflect what Prof. Fernando Moreira da Silva (Silva, 2011) interprets asthe four conditions essential to produce an investigative work in design: "(a) The problem must belong to the disciplinary field of "design"; (b) the methods used must construct themselves into a model that can be applied in futures investigations or in the profession of design itself; (c) the investigation topic must be socially relevant; and (d) the process must always involve the end-users".

\section{Methodology, Hypotheses Development \& Data Analytics}

Table 2. Survey's identity

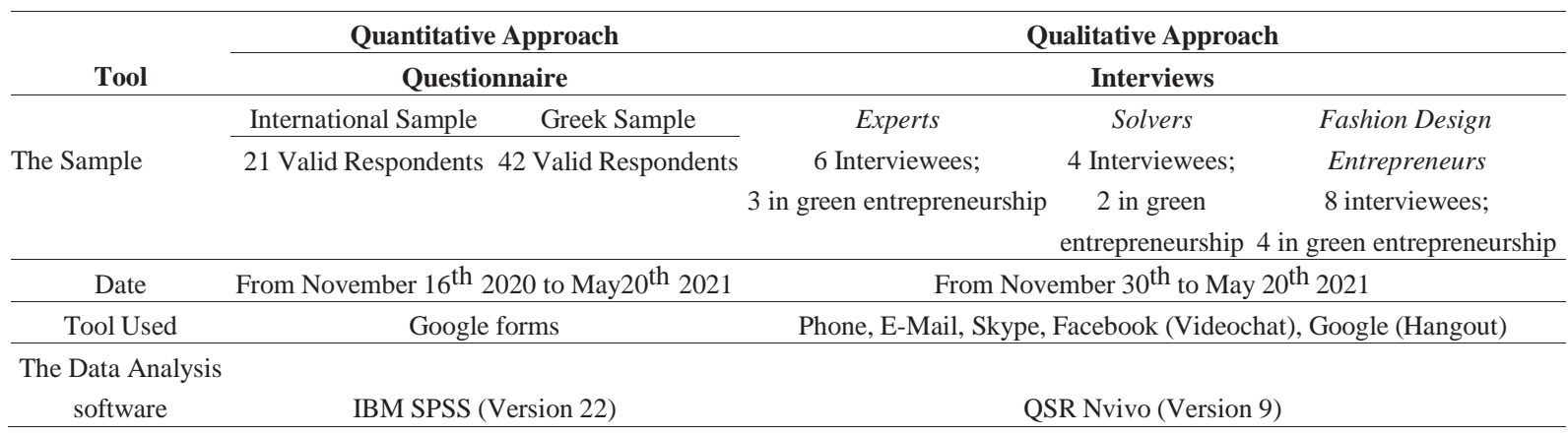

This study employed the use of questionnaires to collect quantitative data and structured interviews to compile qualitative data (opinions) of two main groups of fashion design professionals: (a) clothing merchants and manufacturers, (b) fashion design green entrepreneurs. In particular, linear regression used to analyze the quantitative data (SPSS functionality) and data analytics software (QSR NVivo) adopted to encode the answers from the interviews.

A number of companies and professionals involved in fashion design were surveyed (e.g. Fotini Kiriakati, sole proprietorship in the field of manufacturing and marketing of clothing, FK https://el-gr.facebook.com/fkfashion62; etc.), with the 50\% of them involved in green entrepreneurship fashion design (e.g. Vamp https://vampfashion.com/el/; Euphemia Collection https://gr.pinterest.com/euphemia_collection/ and https://www.etsy.com/shop/EuphemiaCollection; etc.). See Table 2 above (Survey's Identity).

Starting with the quantitative analysis of this study, data obtained among fashion design employees and employers highlight the need for courses to improve their curricula regarding entrepreneurship, as a majority of respondents declared the necessity to develop their knowledge on this topic. Similar result should be found in (Morgan, 2007) and (Holloway \& Wheeler, 2021). Respondents also declared a need for training in digital transformation utilities (big data, business intelligence, product development) and particularly in optimized delivery solutions and social marketing. Finally, a number of higher educated respondents highlighted the importance, in COVID-19 era, of digital consultancy services and solutions, corporate performance management, and creative design/content architecture.

Continuing with the qualitative analysis, the non-green entrepreneurship people rejected the seven hypotheses (14 research questions) with a mean rate of $76 \%$ and considered that they are not prepared (skill, knowledge, and attitude) for the COVID-19 reality and its consequences in the fashion design industry. But, the green entrepreneurship interviewers accepted the seven hypotheses (i.e. the 14 research questions) with a mean rate of 
93\% and considered that they are well prepared (skill, knowledge, and attitude) for the COVID-19 reality or similar crisis. See Table 3 (Survey's Data Analytics):

Table 3: Survey's data analytics

\begin{tabular}{ccc}
\hline $\begin{array}{c}\text { Research } \\
\text { questions }\end{array}$ & $\begin{array}{c}\text { Acceptance rate (\%) } \\
\text { (Non-green entrepreneurship respondents) }\end{array}$ & $\begin{array}{c}\text { Acceptance rate (\%) } \\
\text { (Green entrepreneurship respondents) }\end{array}$ \\
\hline 1 & $18 \%$ & $88 \%$ \\
2 & $20 \%$ & $93 \%$ \\
3 & $16 \%$ & $89 \%$ \\
4 & $12 \%$ & $80 \%$ \\
5 & $22 \%$ & $91 \%$ \\
6 & $29 \%$ & $98 \%$ \\
7 & $33 \%$ & $98 \%$ \\
8 & $35 \%$ & $100 \%$ \\
9 & $22 \%$ & $97 \%$ \\
10 & $23 \%$ & $97 \%$ \\
11 & $32 \%$ & $99 \%$ \\
12 & $29 \%$ & $96 \%$ \\
13 & $20 \%$ & $88 \%$ \\
14 & $25 \%$ & $88 \%$ \\
Mean & $\mathbf{2 4 \%}$ & $\mathbf{9 3 \%}$ \\
\hline
\end{tabular}

\section{Discussion}

The general economic environment remain fluid and it continues to be challenging to anticipate the finally total scope of the COVID-19 pandemic consequences. In this domain, university courses in general (European Commission, 2021, 2018, 2013) and fashion design thinking (skills, attitude, disciplinary, and knowledge gained by young fashion designers during their education and training) in particular, are prepared for the new challenges in entrepreneurship during and beyond this crisis (Global Entrepreneurship Monitor, 2017; Nonaka \& Hirotaka, 2019).

In this dynamically developing international situation, new technologies, software tools, data sciences, and ICT functionalities, like Distributed Ledger Technology/DLT and particularly "ready-to-wear" clothing through Blockchain (Juan José Bullón Pérez et al., 2020), Blockchain data structure with spatial functionalities (Yun et al., 2020), agile technology (Perficient Inc., 2021), (Endana plc., 2021), etc. appear with many promises and spinoff dynamics (Wenting Rik, 2008). By exploring green entrepreneurship in fashion design thinking, this paper aimed to clarify the importance of a continues training in spinoff technologies in order the young fashion designers acquire specific skills, knowledge and attitudes for their journey in this industry and develop clear defensive characteristics in future crises.

The information (actually a data-mining procedure with data analytics functionality) obtained of the conducted survey, presented and discussed in this article, also shows without any doubt that the green entrepreneurship is better positioning to face the challenges in the COVID-19 crisis in both ways: economic and business development with innovation and sustainability. The reason the post COVID-19 pandemic era will be so destructive and creative is that people never have more people had access to: (1) so many money and cheap tools for innovation and design thinking; (2) high-powered remote computing; and (3) such cheap credit to invent new products, tools and services (Friedman, 2020).

Hence, the message is clear! The curriculum in fashion design thinking (whatever training or education) must incorporate green entrepreneurship courses, as well as a taught-bundle of selected topics from the so-called "agile technology" (e.g. Product development \& Optimized delivery; Corporate performance management; Creative design \& Content architecture).

The proposed agile entrepreneurship innovation Action Plan is a blueprint for a decisive action to unleash fashion design entrepreneurial potential in todays' world following digital transformation functionalities, to remove existing obstacles and to revolutionise the skills of entrepreneurship in fashion business. Obviously, investments in changing the public perception of entrepreneurs, in fashion entrepreneurship training and to support young enterpreneurs that are actually under-represented are indispensable if we want to create skills and 
entrepreneurship innovation. An agile entrepreneurship innovation Action Plan should built on three main pillars: (a) Entrepreneurial education and training; (b) creation of an environment where entrepreneurs can flourish and grow; and (c) developing role models and reaching out to specific groups whose entrepreneurial potential is not well operated in situation like the COVID-19 crisis (European Commission, 2021, 2018, 2013).

Finally, the introduction of the "agile entrepreneurship" concept and the definition of it as a term in the fashion design thinking disciplinary, should be considered as the main paper's contribution to fashion design thinking,.

\section{Acknowledgements}

Many heartfelt thanks to the Department of Creative Design \& Clothing / The International Hellenic University (Cities of Kilkis and Thessaloniki, Greece). Also, I am grateful to all survey participants and particularly to Fotini Kiriakati, Vamp SA, and Euphemia Collection.

\section{References}

Clara Eloise Fernandes. (2019). Fashion Design Entrepreneurship: Skills and Solutions to Create a Fashion Business. Journal of Textile Science \& Fashion Technology, 3(1). https://doi.org/10.33552/JTSFT.2019.03.000553

Endana plc. (2021). London, UK. Retrieved from https://www.endava.com

European Commission. (2013). Entrepreneurship 2020 Action Plan. Reigniting the entrepreneurial spirit in Europe. COM (December 17, 2013) 795 (Final report). Retrieved from https://www.smefinanceforum.org/post/the-entrepreneurship-2020-action-plan-reigniting-the-entrepreneuria 1-spirit-in-europe

European Commission. (2018). Entrepreneurship in higher education, especially within non-business studies. Final report of the expert group. Retrieved from https://www.grin.com/document/204563

European Commission. (2021). Entrepreneurship in higher education, especially within non-business studies. Final Report of the Expert Group. file:///C:/Users/30699/Downloads/entr_highed_en.pdf

Friedman, T. (2020). After the Pandemic, a Revolution in Education and Work Awaits. The New York Times. New York City, USA. r Retrieved https://www.nytimes.com/2020/10/20/opinion/covid-education-work.html

Global Entrepreneurship Monitor. (2017). Global Report 2016/2017.

Harvard Business Review. (2016). Retrieved from https://hbr.org/2016/05/embracing-agile

Holloway, I., \& Wheeler, S. (2021). The nature and utility of qualitative research. Journal Introduction to Qualitative Research: Initial Stages. Retrieved from https://nursekey.com/the-nature-and-utility-of-qualitative-research/

Manzini, E. (2012). Design schools as agents of (sustainable) change: A Design Labs Network for an Open Design Program. DIS Politecnico di Milano - DESIS Network (www.desis-network.org). Retrieved from https://silo.tips/download/design-schools-as-agents-of-sustainable-change-a-design-labs-network-for-an-ope $\mathrm{n}$

Moreira, D. S. F. (2011). Investigar em design versus investigar pela prática do design- um novo desafio científico. INGEPRO - Inovação, Gestão e Produção, 2(4), 82-91. Retrieved from https://www.yumpu.com/pt/document/view/14405570/investigar-em-design-versus-investigar-pela-praticado-design

Morgan, D. L. (2007). Paradigms Lost and Pragmatism Regained: Methodological Implications of Combining Qualitative and Quantitative Methods. Journal of Mixed Methods Research, 1(1), 48-76. https://doi.org/10.1177/2345678906292462

Mwasalwiba, E. S. (2010). Entrepreneurship Education: A review of its objectives, teaching methods, and impact indicators. Journal Education + Training, 52(1), 20-47. https://doi.org/10.1108/00400911011017663

Nonaka, I., \& Hirotaka, T. (2019). The Wise Company: How Companies Create Continuous Innovation. New York: Oxford University Press / City of New York, 2019. Retrieved from https://www.hbs.edu/faculty/Pages/item.aspx?num=56978

Patrice, M., Jenna, J., Daniel, H., ... \& Sean, M. (2017). SMEs and entrepreneurship in the EU, Annual report on European SMEs 2016/2017, Focus on Self-Employment.

Pérez, J. J. B., Queiruga-Dios, A., Víctor, G. M., \& Ángel, M. R. (2020). Traceability of Ready-to-Wear Clothing 
through Blockchain Technology. Journal Sustainability, 12, 7491. https://doi.org/10.3390/su12187491

Perficient Inc. (2021). St Louis, Missouri, USA. Retrieved from https://www.perficient.com

Rigby, Darrell K., Jeff Sutherland, and Hirotaka Takeuchi (2016). Embracing Agile: How to Master the Process That's Transforming Management. Harvard Business Review, 94(5), 40-50. Retrieved from https://www.hbs.edu/faculty/Pages/item.aspx?num=51051

Runco, M. A. (2014). Creativity Theories and themes: Research, development, and practice (2nd ed.). Elsevier Academic Press. https://psycnet.apa.org/record/2014-12783-000

Segonds, F., Mantelet, F., Maranzana, N., \& Gaillard, S. (2020). Early stages of apparel design: how to define collaborative needs for PLM and fashion? (Version 2). International Journal of Fashion Design, Technology and Education, 7(2), 105-114. https://doi.org/10.1080/17543266.2014.893591

Wenting, R. (2008). Spinoff dynamics and the spatial formation of the fashion design industry, 1858-2005. Journal of Economic Geography, 8(5), 593-614. https://doi.org/10.1093/jeg/lbn030

Yun, Z., Zhi, T., Jing, H., Yue, D., Hao, H., Xiaosheng, X., \& Chunhua. (2020). A Decentralized Model for Spatial Data Digital Rights Management. International Journal of Geo-information / ISPRS, 9, 84. https://doi.org/10.3390/ijgi9020084

\section{Copyrights}

Copyright for this article is retained by the author(s), with first publication rights granted to the journal.

This is an open-access article distributed under the terms and conditions of the Creative Commons Attribution license (http://creativecommons.org/licenses/by/4.0/). 